\title{
Individualized Strategies in the Era of Combination Antiretroviral Therapy
}

\author{
Ronald H. Goldschmidt, MD, Kirsten B. Balano, PharmD, Jill J. Legg, MD, \\ and Betty J. Dong, PbarmD
}

Combination antiretroviral therapy can produce unprecedented improvements in survival, laboratory markers, opportunistic infections, and quality of life in persons infected with the human immunodeficiency virus (HIV). Potent drug combinations that include a protease inhibitor are now considered standard therapy for persons with HIV infection. For these regimens to be successful, clinicians must devote special attention to explaining the correct use of these agents, their risks and benefits, their toxicities and drug interactions, and the importance of good adherence. Although many primary care clinicians are not as familiar with these drug combinations as they are with the treatment of other complex diseases, antiretroviral management of HIV-infected persons is within the purview of most family physicians and other primary care providers.

Recent guidelines released by the Department of Health and Human Services (DHHS) ${ }^{1}$ and the International AIDS Society ${ }^{2}$ provide therapeutic principles and specific recommendations for the use of antiretroviral drugs in adults and adolescents infected with HIV. Both these guidelines are markedly similar in their recommendations; a version of the DHHS guidelines is available on the Internet at www.hivatis.org. Final recommendation by the DHHS will be published in the Morbidity and Mortality Weekly Report in 1998.

These and other ${ }^{3}$ recommendations provide helpful guidelines for antiretroviral treatment.

Submitted 1 August 1997.

From the Family Practice Residency Program, San Francisco General Hospital, and the Departments of Family and Community Medicine (RHG, KBB, JJL, BJD) and Clinical Pharmacy (KBB, BJD), University of California, San Francisco. Address reprint requests to Ronald $\mathrm{H}$. Goldschmidr, MD, Family Practice Inpatient Service, San Francisco General Hospital, San Francisco, CA 94110.

Supported in part by the Pacific AIDS Education and Training Center, Grant No. 2 U69 PE00118-05, with the Bureau of Health Professions, Health Resources and Services Administration, Department of Health and Human Services.
Following these guidelines and new developments in therapy, however, can be a complex task because the primary care clinician must take into account drug toxicities, drug-drug interactions, patient preferences, and other factors that can profoundly affect adherence.

This update of our previous antiretroviral strategies recommendations, ${ }^{4-6}$ summarizes the DHHS guidelines and also provides our suggestions to optimize and individualize antiretroviral therapy. Treatment of primary HIV infection is extensively discussed in the guidelines but will not be included in this review. Special attention is paid to primary care issues relevant to the treatment of established HIV infection, such as proper patient selection and promotion of the safe and effective use of antiretroviral medications. These issues are key to primary HIV care for generalists and specialists alike, as nonadherence to therapy can be associated with poor outcomes.

\section{Viral Load Testing}

Plasma HIV RNA (viral load) tests are now widely available and essential for making antiretroviral treatment decisions. Although the CD4+ lymphocyte count is still the best measure of the underlying degree of immunosuppression, baseline plasma HIV RNA determination is a better predictor of long-term prognosis. The two most common assays used are the branched DNA (bDNA) assay and the reverse transcriptase polymerase chain reaction (RT-PCR) assay. The RTPCR assay gives results that are roughly twofold higher than the bDNA assay.

Viral load testing is generally performed every 3 to 4 months. For an individual patient the same test should be followed to permit accurate comparisons of viral load trends. Two measurements should be drawn at baseline and before considering changes in antiretroviral therapy based on viral load test results. Because there is considerable 
Table 1. Indications for the Initiation of Antiretroviral Therapy in the Chronically HIV-Infected Patient.

\begin{tabular}{|c|c|c|}
\hline Clinical Category & CD4+ Cell Count and HIV RNA & Recommendation \\
\hline $\begin{array}{l}\text { Symptomatic (AIDS, thrush, } \\
\text { unexplained fever) }\end{array}$ & Any value & Treat \\
\hline Asymptomatic & $\begin{array}{l}\text { CD4+ T cells }<500 / \mu \mathrm{L} \\
\text { or } \\
\text { HIV RNA }>10,000(\mathrm{bDNA}) \\
\text { or }>20,000(\mathrm{RT}-\mathrm{PCR})\end{array}$ & $\begin{array}{l}\text { Treatment should be offered. Strength of } \\
\text { recommendation is based on prognosis } \\
\text { for disease-free survival and willingness of the } \\
\text { patient to accept therapy }\end{array}$ \\
\hline Asymptomatic & $\begin{array}{l}\mathrm{CD} 4+\mathrm{T} \text { cells }>500 / \mathrm{\mu L} \\
\text { and } \\
\mathrm{HIV} \text { RNA }<10,000(\mathrm{bDNA}) \\
\text { or }<20,000(\mathrm{RT}-\mathrm{PCR})\end{array}$ & $\begin{array}{l}\text { Some experts would delay therapy and } \\
\text { observe; however, some experts would treat }\end{array}$ \\
\hline
\end{tabular}

bDNA - branched DNA; RT-PCR - reverse transcriptase polymerase chain reaction.

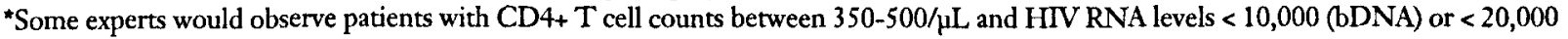
(RT-PCR).

Adapted from: Guidelines for the use of antiretroviral agents in HIV-infected adults and adolescents. www.hivatis.org. ${ }^{1}$

biological and laboratory variability in viral load determinations, only changes that are greater than threefold $\left(0.5 \log _{10}\right)$ are considered to be clinically meaningful.

Viral load measurements should not be done within 1 month of an acute illness or immunization because both can cause transient rises in viral load. In addition, it is essential that proper specimen handling procedures be followed, as these can substantially affect test results.

\section{When to Treat}

The major objectives of antiretroviral therapy are to prevent disease progression, prolong survival, and improve the quality of life. Aggressive suppression of plasma viral load to undetectable levels with triple drug therapy might be necessary to attain these goals, but long-term data are not yet available. Furthermore, the feasibility of achieving undetectable viral levels is dependent on the susceptibility of the virus to available agents and is contingent upon the patient's adherence to treatment. Ideally and if clinically tolerable, all patients with the acquired immunodeficiency syndrome (AIDS) or symptomatic HIV disease should receive antiretroviral therapy, including a protease inhibitor, to reduce viral loads to undetectable levels. Table 1 summarizes indications for starting therapy.

For asymptomatic HIV-infected persons, the optimal time to initiate therapy remains somewhat controversial, although ideally treatment should begin before substantial damage to the immune system has occurred. Assessing the risk of disease progression might help sort out those most likely to benefit from treatment. The guidelines provide a table for estimating the prognosis for diseasefree survival. Because disease progression is more likely if the CD4+ lymphocyte count is less than $500 / \mu \mathrm{L}$ or the viral load is greater than 10,000 copies/mL (bDNA assay) or greater than 20,000 copies/mL (RT-PCR assay), treatment is recommended. Some experts would defer treatment for patients with $\mathrm{CD} 4+$ lymphocyte counts of 350 to $500 / \mu \mathrm{L}$ and low viral load test results; others would treat all patients with any detectable virus, regardless of CD4+ lymphocyte counts. Because it is not yet known whether a more aggressive or a more conservative approach ${ }^{3}$ to treatment is most beneficial, both approaches should be discussed with asymptomatic patients.

\section{Initiating Antiretroviral Treatment}

The guidelines recommend starting with potent treatment regimens whenever possible to achieve undetectable viral levels: drug therapy consisting of two nucleoside reverse transcriptase inhibitors (NRTIs) and a protease inhibitor. Table 2 reviews the DHHS recommendations for initial aptiretroviral regimens, and Table 3 lists the currently available antiretroviral drugs.

Before starting antiretroviral therapy, it is imperative to take enough time to discuss fully the potential risks and benefits of antiretroviral therapy with the patient. A key concern is to establish a strategy that will avoid the development of drug resistance, which can occur rapidly with inconsistent administration of these agents, particularly with the protease inhibitors. Likewise, resistance to the nonnucleoside reverse transcriptase in- 
Table 2. Recommended Antiretroviral Agents for Treatment of Established HIV Infection.

\begin{tabular}{|c|c|c|c|}
\hline Recommendation & Strength of Evidence & \multicolumn{2}{|c|}{ Antiretroviral Agents } \\
\hline \multirow[t]{3}{*}{ Preferred } & \multirow[t]{3}{*}{$\begin{array}{l}\text { Strong evidence of clinical benefit and } \\
\text { sustained suppression of plasma viral load }\end{array}$} & \multicolumn{2}{|c|}{$\begin{array}{l}\text { One choice each from column } \mathrm{A} \text { and } 2 \text { from column } \mathrm{B} \text {. } \\
\text { Drugs are listed in random, not priority, order: }\end{array}$} \\
\hline & & Column A & Column B \\
\hline & & $\begin{array}{l}\text { Indinavir } \\
\text { Nelfinavir } \\
\text { Ritonavir } \\
\text { Ritonavir + } \\
\text { saquinavir }\end{array}$ & $\begin{array}{l}\mathrm{ZDV}+\mathrm{ddI} \\
\mathrm{d} 4 \mathrm{~T}+\mathrm{ddI} \\
\mathrm{ZDV}+\mathrm{ddC} \\
\mathrm{ZDV}+3 \mathrm{TC} \\
\mathrm{d} 4 \mathrm{~T}+3 \mathrm{TC}^{*}\end{array}$ \\
\hline Alternative & $\begin{array}{l}\text { Less likely to provide sustained virus } \\
\text { suppression; clinical benefit is undetermined }\end{array}$ & \multicolumn{2}{|c|}{$\begin{array}{l}1 \text { NNRTI (nevirapine) }{ }^{\dagger}+2 \text { NRTIs (column B, above) } \\
\text { Saquinavir + } 2 \text { NRTIs (column B, above) }\end{array}$} \\
\hline $\begin{array}{l}\text { Not generally } \\
\text { recommended }\end{array}$ & $\begin{array}{l}\text { Clinical benefit demonstrated but initial virus } \\
\text { suppression is not sustained in most patients }\end{array}$ & \multicolumn{2}{|c|}{2 NRTIs (column B, above) } \\
\hline $\begin{array}{l}\text { Not } \\
\text { recommended }\end{array}$ & $\begin{array}{l}\text { Evidence against use, virologically undesirable, } \\
\text { or overlapping toxicities }\end{array}$ & \multicolumn{2}{|l|}{$\begin{array}{l}\mathrm{d} 4 \mathrm{~T}+\mathrm{ZDV} \\
\mathrm{ddC}+\mathrm{ddI} \\
\mathrm{ddC}+\mathrm{d} 4 \mathrm{~T} \\
\mathrm{ddC}+3 \mathrm{TC} \\
\text { All monother }\end{array}$} \\
\hline
\end{tabular}

Adapted from: Guidelines for the use of antiretroviral agents in HIV-infected adults and adolescents. www.hivatis.org.

NRTI - nucleoside reverse transcriptase inhibitor; NNRTI - nonnucleoside reverse transcriptase inhibitor; ZDV - zidovudine; ddI - didanosine; d4T - stavudine; ddC - zalcitabine; 3TC - lamivudine.

"High level resistance to 3 TC develops within 2-4 weeks in partially suppressive regimens: optimal use is in 3-drug antiretroviral combinations that reduce viral load to $<500$ copies $/ \mathrm{mL}$.

The only combination of 2 NRTIs +1 NNRTI that has been shown to suppress viremia to undetectable levels in the majority of patients is zidovudine+didanosine+nevirapine. This combination was studied in antiretroviral-naive persons.

hibitors (NNRTIs) and lamivudine (3TC) develops rapidly if incomplete viral suppression occurs. These agents appear most effective when used in a triple drug regimen. Poor adherence not only causes resistance to drugs in the current regimen but might also limit future options because of high levels of cross-resistance that can occur among these agents. Counseling patients about their treatment options often takes several visits but is well worth the investment of time and attention if it can promote commitment and good adherence to treatment. The guidelines acknowledge that it is sometimes better to defer treatment or to avoid protease inhibitor-containing regimens for some patients until they are able to adhere fully to a rigorous medication regimen.

Alternatives to protease inhibitor-containing regimens are provided in Table 3 . Nevirapine can be substituted for the protease inhibitor in the initial triple drug regimen. The NNRTIs are less potent antiviral agents than the protease inhibitors but might be used if protease-inhibitorcontaining regimens are not possible. Clinical data are not available to decide when an NNRTI is preferred to protease inhibitors. Available data suggest that the NNRTIs exert their most potent effects in persons who have never taken antiretroviral drugs. Information about the clinical efficacy and drug interactions of delavirdine is limited; the role of delavirdine in antiretroviral therapy is not established. Cross-resistance exists between NNRTIs, limiting use of the alternative . agent in instances of failure.

Although double NRTI therapy has better clinical outcomes than no therapy or monotherapy, double NRTI therapy is not considered optimal for complete viral suppression and long-term clinical benefit. Monotherapy is no longer recommended because it is less effective and induces more rapid drug resistance. In addition, certain drug combinations should be avoided. Stavudine (d4T) and zidovudine (ZDV) have antagonistic antiviral effects that can lead to a decrease in CD4+ lymphocyte counts. The combination of zalcitabine (ddC) with didanosine (ddI) or stavudine is not recommended because of an increased risk of peripheral neuropathy and pancreatitis. Because saquinavir is poorly absorbed and considered less potent than other available protease inhibitors, saquinavir generally should not be used as part of a double NRTI and single protease inhibitor regimen. 
Table 3. Antiretroviral Drugs Currently Approved by the Food and Drug Administration

\begin{tabular}{|c|c|c|c|c|}
\hline Drug & $\begin{array}{l}\text { Recommended } \\
\text { Dosage }\end{array}$ & How to Take & $\begin{array}{l}\text { Common Adverse } \\
\text { Reactions }\end{array}$ & $\begin{array}{l}\text { Cytochrome P-450 } \\
\text { Enzyme Effects }\end{array}$ \\
\hline \multicolumn{4}{|l|}{$\begin{array}{l}\text { Nucleoside reverse transcriptase } \\
\text { inbibitors (NRTLs) }\end{array}$} & \\
\hline $\begin{array}{l}\text { Zidovudine (ZDV, } \\
\text { AZT, Retrovir) }^{\star}\end{array}$ & $\begin{array}{l}300 \mathrm{mg} \text { bid or } \\
200 \mathrm{mg} \text { tid }\end{array}$ & $\begin{array}{l}\text { Better tolerated if taken } \\
\text { with food }\end{array}$ & $\begin{array}{l}\text { Anemia, neutropenia } \\
\text { headaches, nausea }\end{array}$ & None \\
\hline $\begin{array}{l}\text { Didanosine (ddI, } \\
\text { Videx) }\end{array}$ & $\begin{array}{l}200 \mathrm{mg} \text { bid for } \\
\text { patients }>60 \mathrm{~kg}\end{array}$ & $\begin{array}{l}\text { Take on empty stomach } \\
2 \text { tablets with each dose } \\
\text { Separate from other } \\
\text { medications }\end{array}$ & $\begin{array}{l}\text { Peripheral neuropathy } \\
\text { pancreatitis }\end{array}$ & None \\
\hline Zalcitabine (ddC, Hivid) & $0.75 \mathrm{mg}$ tid & $\begin{array}{l}\text { Take with or without } \\
\text { food }\end{array}$ & $\begin{array}{l}\text { Peripheral neuropathy, } \\
\text { oral ulcers }\end{array}$ & None \\
\hline Stavudine (d4T, Zerit) & $20-40 \mathrm{mg}$ bid & $\begin{array}{l}\text { Take with or without } \\
\text { food }\end{array}$ & Peripheral neuropathy & None \\
\hline $\begin{array}{l}\text { Lamivudine (3TC, } \\
\text { Epivir) }\end{array}$ & $150 \mathrm{mg}$ bid & $\begin{array}{l}\text { Take with or without } \\
\text { food }\end{array}$ & Headaches, nausea & None \\
\hline \multicolumn{5}{|c|}{$\begin{array}{l}\text { Nonnucleoside reverse transcriptase } \\
\text { inbibitors (NNRTIs) }\end{array}$} \\
\hline Nevirapine (Viramune) & $\begin{array}{l}200 \mathrm{mg} \mathrm{bid} \\
\text { Start } 200 \mathrm{qd} \\
\text { for } 2 \text { weeks }\end{array}$ & $\begin{array}{l}\text { Take with or without } \\
\text { food }\end{array}$ & Rash & Induces liver enzymes \\
\hline Delavirdine (Rescriptor) & $400 \mathrm{mg}$ tid & $\begin{array}{l}\text { Take with or without } \\
\text { food }\end{array}$ & Rash & Inhibits liver enzymes \\
\hline \multicolumn{5}{|l|}{ Protease inbibitors } \\
\hline Indinavir (Crixivan) & $800 \mathrm{mg} \mathrm{q} 8 \mathrm{~h}$ & $\begin{array}{l}\text { Take on empty stomach } \\
\text { or with light meals } \\
\text { Drink } 1.5 \mathrm{~L} \text { of water } \\
\text { daily }\end{array}$ & $\begin{array}{l}\text { Hyperbilirubinemia, } \\
\text { nephrolithiasis }\end{array}$ & Inhibits liver enzymes \\
\hline Nelfinavir (Viracept) & $750 \mathrm{mg}$ tid & $\begin{array}{l}\text { Best tolerated if taken } \\
\text { with food }\end{array}$ & $\begin{array}{l}\text { Diarrhea, nausea, } \\
\text { vomiting }\end{array}$ & Inhibits liver enzymes \\
\hline $\begin{array}{l}\text { Ritonavir (Norvir) } \\
\text { plus either saquivir } \\
\text { soft-gel capsule (SGC, } \\
\text { Fortavase) or hard-gel } \\
\text { capsule (HGC, Invirase) }\end{array}$ & $\begin{array}{l}400 \mathrm{mg} \text { bid } \\
\text { of each }\end{array}$ & See below & See below & See below \\
\hline $\begin{array}{l}\text { Saquinavir soft-gel } \\
\text { capsule (SGC, Fortavase) }\end{array}$ & $1200 \mathrm{mg}$ tid & Take with high-fat meals & $\begin{array}{l}\text { Diarrhea, nausea, } \\
\text { abdominal pain }\end{array}$ & Inhibits liver enzymes \\
\hline Ritonavir (Norvir) & $\begin{array}{l}600 \mathrm{mg} \mathrm{bid} \\
\text { Start } 300 \text { bid and } \\
\text { increase slowly } \\
\text { over } 1 \mathrm{wk}\end{array}$ & $\begin{array}{l}\text { Best tolerated if taken } \\
\text { with food } \\
\text { Requires cool } \\
\text { environment }\end{array}$ & $\begin{array}{l}\text { Diarrhea, nausea, } \\
\text { vomiting, } \\
\text { abdominal pain }\end{array}$ & $\begin{array}{l}\text { Potent inhibitor of } \\
\text { liver enzymes }\end{array}$ \\
\hline
\end{tabular}

*Available in fixed-dose capsule of zidovudine, $300 \mathrm{mg}$, plus lamivudine, $150 \mathrm{mg}$ (Combivir).

\section{Changing Antiretroviral Treatment}

Changes in antiretroviral regimens become necessary when drug intolerance or treatment failure occurs. Assessing whether underlying illness or drug toxicity is causing symptoms can be difficult. For drug intolerance or toxicity, an assessment of the drug or drugs responsible is essential. If one drug is clearly causing side effects, it should be discontinued and another drug within the same class substituted promptly. If there is considerable toxicity, and it is not clear which drug is the cause, the entire regimen might need to be stopped. To prevent the development of drug resistance, it is probably best to stop all antiretroviral drugs until toxicity abates. Resuming therapy must be individualized.

Another reason to change a regimen is treatment failure. Treatment failure should be considered in patients who have clinical deterioration (eg, worsening symptoms, new AIDS-defining illnesses), declining CD4+ lymphocyte counts, or incomplete suppression of viral load. Resistance to even the most potent regimens is common after incomplete suppression of viral replication. Viral load testing is usually performed 4 weeks after changing therapy. A potent regimen should 
suppress viral load rapidly, decreasing viral load 10 -fold by 4 weeks and to undetectable levels by 4 to 6 months. If a rapidly decreasing viral load does not occur, the patient should be assessed for poor adherence, malabsorption, drug interactions, or intercurrent illnesses. If no other explanations can be found, resistance to the current regimen has likely occurred. A confirmed viral rebound after a period of undetectability is another reason to consider changing therapy.

Some patients' response to treatment is less than ideal, especially if there is a history of extensive antiretroviral therapy. For these patients, achieving an undetectable viral load might not be possible, and a more modest reduction in viral load might be a reasonable goal of therapy. Resistance testing is under intense investigation but is not recommended at this time for use in guiding antiretroviral treatment decisions.

When changing treatment, it is essential to perform a complete review of previous antiretroviral therapy. The goal is to find three new drugs that the patient has never taken and that are unlikely to be cross-resistant to drugs previously used. If doing so is not possible, at least two drugs in the regimen should be changed. Changing only one drug of a failing regimen is equivalent to sequential monotherapy and should be avoided, as it has been shown to be inadequate. Because the first protease inhibitor-containing regimen has the best chance of achieving durable viral load reductions, subsequent changes in regimens might not result in a durable response. There is concern about high levels of cross-resistance among the protease inhibitors. Combination protease inhibitor therapy or an NNRTI combined with a protease inhibitor can be used for patients with limited options. For clinically stable patients who have limited treatment options, it might be reasonable to delay changing therapy until newer drugs are available. Some experimental drugs are curently available through expanded access programs. Consultation with providers experienced in managing antiretroviral therapy can be helpful when making these sometimes complex decisions.

\section{Adherence}

The key to the success of any antiretroviral regimen is the patient's ability to adhere to it. Primary care clinicians need to recognize potential barriers to adherence. Factors to consider when choosing a regimen include how often the drugs need to be administered, their timing in relation to meals, common side effects, drug-drug interactions, cost, and psychosocial issues. Although homelessness, active drug use, and mental illness can make adherence more difficult, treatment decisions should be individualized without excluding certain groups of patients from treatment.

\section{Dosing}

Most medications can be taken twice daily, although delavirdine, saquinavir, indinavir, and nelfinavir must be taken three times a day. Adherence to indinavir-containing regimens is especially challenging, because indinavir must be taken every 8 hours around the clock (not three times daily) on an empty stomach (1 hour before or 2 hours after meals) to ensure effective serum levels. Indinavir can also be taken with a light meal, such as cereal or toast, if necessary, to minimize nausea. Saquinavir should be taken with a high-fat meal to maximize absorption. Didanosine should be administered on an empty stomach and separate from other medications because the buffered tablet interferes with the absorption of many drugs used in treating HIV disease, including indinavir, ritonavir, and delavirdine. ${ }^{4} \mathrm{~A}$ regimen containing both didanosine and indinavir can be complicated, as both medications should be separated from each other by 1 hour and also separated from meals. The capsule formulation of ritonavir should not be . kept in direct sunlight or in hot conditions, which eliminates its use for some patients.

\section{Toxicity}

The toxicity profile of each drug should be considered carefully before selecting an antiretroviral regimen. The most common toxicities are noted in Table 3. Nausea, vomiting, and other gastrointestinal complaints occur with all the available medications but are most problematic with didanosine and the protease inhibitors. Of the protease inhibitors, ritonavir is most likely to cause gastrointestinal problems. Beginning with a low dosage and escalating gradually can decrease the incidence of ritonavir side effects. Diarrhea is common during the first few months of nelfinavir treatment but usually can be managed with standard antidiarrheal medications. Nephrolithiasis caused by drug crystallization is a unique complication of indinavir therapy and can be minimized 
by advising patients to drink at least $1.5 \mathrm{~L}$ of noncaffeinated beverages daily. Routine laboratory monitoring (including complete blood counts, liver function tests, and renal panels) should be performed about every 3 or 4 months for all patients taking antiretroviral agents. Hepatotoxicity can occur with all the drugs, but patients with underlying liver disease are at greatest risk. Because recent reports suggest that protease inhibitors might cause hyperglycemia and diabetes mellitus, blood glucose should be monitored regularly. $\mathrm{Hy}$ perlipidemia also occurs with protease inhibitor use and requires monitoring.

\section{Drug Interactions}

With the introduction of the protease inhibitors and the NNRTIs, drug interactions have become more complex. Both classes of drugs have potent effects on the hepatic cytochrome P-450 enzyme system that is involved in the metabolism of many drugs. All the protease inhibitors and delavirdine are enzyme inhibitors. Enzyme inhibitors reduce the metabolism of drugs by the cytochrome P-450 system, leading to increases in their serum levels and sometimes increased toxicity or efficacy. For example, the protease inhibitors and delavirdine inhibit the metabolism of terfenadine, astemizole, and cisapride. Because increased serum levels of these drugs can lead to cardiac arrhythmias, their use is contraindicated with the protease inhibitors and delavirdine. Ritonavir is an especially potent enzyme inhibitor, causing considerably more drug interactions than the other protease inhibitors. Many medications are contraindicated for use with ritonavir, including most of the benzodiazepines. In some cases, drug interactions with the protease inhibitors have been beneficial. Ritonavir increases saquinavir serum levels more than 20fold, leading to potent antiviral effects. When using this combination, saquinavir can be given at a lower dosage of $400 \mathrm{mg}$ twice daily with ritonavir $400 \mathrm{mg}$ twice daily.

Enzyme inducers, such as rifampin, rifabutin, and nevirapine, increase the metabolism of drugs metabolized by the cytochrome P-450 system (eg, protease inhibitors), resulting in decreases in their serum levels and possible decreased efficacy. The combination of rifampin with protease inhibitors and NNRTIs is not recommended because loss of antiviral activity can occur. If necessary, rifabutin can be used cautiously with the NNRTIs or pro-
Table 4. Practical Aspects of Adherence: Improvement Strategies.

1. Educate patients thoroughly about all medications

2. Make patient preferences an integral part of treatment decisions

3. Simplify regimen when possible; eliminate other nonessential drugs

4. Review medications at each visit

5. Suggest individual dosing kits (Mediset and others), alarms, and other reminders for taking medications

6. Address social issues that might be barriers to adherence

tease inhibitors if appropriate dosage adjustments are made. The DHHS guidelines provide these dosage adjustments, as well as guidelines for dosage adjustments, when using protease inhibitors along with NNRTIs. Most of these recommendations are based on limited pharmacokinetic data. The guidelines also contain a complete table of drug interactions. Medication profiles should be reviewed carefully before initiating protease inhibitor or NNRTI therapy and before other new drugs are added.

\section{Cost}

The combined cost of the medications, ranging from $\$ 12,000$ to $\$ 15,000$ per year, can be substantial and result in nonadherence. Although the AIDS Drug Assistance Program and most insurance programs can provide financial assistance, clinicians should find out whether reimbursement for these drugs will be continuously available for individual patients.

\section{Practical Aspects of Adberence}

Patients who understand and to some degree choose their own medication regimen are better able to achieve good adherence. It is crucial for primary care providers to take the time necessary to provide appropriate counseling about antiretroviral regimens, and such counseling often takes several visits. Patients can also be referred to sources that provide HIV treatment information to the general public. By reviewing available options, dosing schedules, toxicities, and drug interactions, primary care providers can help guide patients to make their own decisions about treating their HIV infection.

Adherence requires ongoing communication between patient and provider. Some tools that have been useful in this process include having the 
patient bring all medications to each visit and asking open-ended questions about which medications are currently being taken and how often. Some patients find dosing kits or alarm reminders useful tools for remembering complicated regimens. It is also important for clinicians to address social issues that can interfere with adherence. For example, stable housing, regular meals, and assistance in the home with administering medication have allowed some patients to adhere to regimens that were otherwise too complicated. Some strategies to improve adherence are shown on Table 4.

\section{Conclusion}

Combination antiretroviral therapy is now recommended for most HIV-infected persons. All current guidelines recommend the most potent combination: triple drug protease inhibitor-containing regimens.

The most effective antiretroviral regimen, however, is the one the patient actually takes. The primary care clinician must consider not only drug potency but also the patient's ability to tolerate and adhere to medication regimens when developing an antiretroviral strategy. If a patient is not able or cannot be commited to take lifelong combination therapy, delaying therapy until adherence can be sustained is advisable.
Clinicians should also be aware of available resources that can provide updated information and clinical guidance in managing antiretroviral therapy. Further information is available in the articles cited, at Internet sites, and through our $\mathrm{Na-}$ tional HIV Telephone Consultation Service (Warmline) at 1-800-993-3413.

\section{References}

1. Guidelines for the use of antiretroviral agents in HIV-infected adults and adolescents. Panel on Clinical Practices for Treatment of HIV Infection. www.hivatis.org.

2. Carpenter CC, Fischl MA, Hammer SM, Hirsch MS, Jacobsen DM, Katzenstein DA, et al. Antiretroviral therapy for HIV infection in 1997. Updated recommendations of the International AIDS Society -USA Panel. JAMA 1997;277:1962-9.

3. British HIV Association guidelines for antiretroviral treatment of HIV seropositive individuals. BHIVA Guidelines Co-ordinating Committee. Lancet 1997; 349:1086-92.

4. Goldschmidt RH, Dong BJ. Treatment of AIDS and HIV-related conditions-1997. J Am Board Fam Pract 1997;10:144-67.

5. Goldschmidt RH, Dong BJ, Legg JJ. Antiretroviral strategies revisited. J Am Board Fam Pract 1995; 8:62-9.

6. Goldschmidt RH, Moy A. Antiretroviral drug treatment for HIV/AIDS. Am Fam Physician 1996;54: 574-80, 587-8. 